\title{
International Tax Jurisdiction Review Of Government Decisions Regarding The Obligation To Process Nickel Mining Products Into Finished Goods Before Exporting
}

\author{
Agus Tyono Amas Noer* \\ ${ }^{*}$ Graduated Student, Institute STIAMI Jakarta \\ ${ }^{* *}$ Tax Administration Programs \\ DOI: 10.29322/IJSRP.11.08.2021.p11607 \\ http://dx.doi.org/10.29322/IJSRP.11.08.2021.p11607
}

\begin{abstract}
Through this research to provide an analysis of a policy related to international Taxation in Indonesia. After the issuance of Law no. 4 of 2009 issued by the Government has a very significant impact on the future of the economy of other countries, especially on the import of Nickel raw material, which is the main material for various businesses such as automotive and others. Other countries Producers need raw materials for Nickel and different types of minerals from Indonesia. The policy of the Government of Indonesia is to expect more benefits from the downstream policy of mineral and coal in the country to achieve the interests of national development and sustainability. The research will describe the direction of the Indonesian Government's policy on policies and relations between countries in terms of the concept of the National Interest through the International Tax Jurisdiction Review approach.
\end{abstract}

Keywords: Mining Tax, Nickel Mining, Indonesian Tax Policy

\section{PRELIMINARY}

Indonesia is a country that produces minerals that are very large and have many types. The amount of mineral content in Indonesia consists of tin, gold, diamond, silver, copper, coal, bauxite, oil, etc. According to data from the Indonesian Mining Association in 2014, the number of mineral reserves in Indonesia can be seen in the following table.

Indonesia on World Mineral Ranking Table

\begin{tabular}{llll}
\hline Minerals Type & $\begin{array}{l}\text { Percentage of Order } \\
\text { Quantity / Production }\end{array}$ & $\begin{array}{l}\text { World Ranking Type } \\
\text { Minerals from the } \\
\text { world's }\end{array}$ & World's Reserves \\
\hline
\end{tabular}

$\begin{array}{lllc}\text { Nickel } & 2,9 & 8 & 4 \\ \text { Gold } & 2,5 & 7 & 6 \\ \text { Copper } & 4,1 & 7 & 10,4 \\ \text { Tin } & 8,1 & 5 & \text { Unknown }\end{array}$

From the table above, the magnitude of the potential that exists in Indonesia gives positive hope in the world of mining investment. Other data explains that the amount of investment in the mining sector from 2010 to 2014 experienced growth. In 2010 the total investment in the mining sector in Indonesia was US\$ 4,373 million. Then until 2014, there was a significant increase to US\$ 7,430 million. The data is based on the Strategic Plan of the Directorate General of Mineral and Coal, 2015-2019.

In particular, the realization of Nickel mining results in Indonesia resulted in an increased production wherein 2010 it was 7 million tons. In 2011 it was 32 million tons, In 2012 it was 41 million tons, and in 2013 it was 56 million tons. As production increases, exports of raw minerals (ore) also increase. Based on data from the Directorate General of Minerals and Coal, it is known that there was a significant increase in exports from 2008 to 2011. This is because the Government of Indonesia has not yet implemented policies that regulate refining processing activities in this sector through the Directorate General of Mineral and Coal. Then, in the end, the Government considered that if the mineral export policy were sent out in the form of raw minerals (ore), the value obtained would be smaller than if the nickel mining production was refining first.

Therefore, the Government issued a policy of increasing added value through Law Number 4 of 2009 concerning Mineral and Coal Mining, which regulates the obligation for refining processing for raw minerals before export. The policy is stated in articles 102 and 103, which state that: 
"IUP and IUPK holders are required to increase the added value of mineral or coal resources in the implementation of mining, processing, and refining, as well as the utilization of minerals and coal."

Then in 2019, after the Mining Law No. 4 of 2009 concerning the obligation for refining processing for raw minerals before export. The Government issued a derivative regulation by giving PP Number 81 of 2019 concerning tariffs on non-tax state revenues. Regulates the nickel royalty rate, which will increase to $10 \%$.

This Government Regulation Number 81 of 2019 was signed by the Government of Indonesia on November 25, 2019, and declared effective as of December 25, 2019. With the enactment of this Government Regulation, we firmly stop the export of raw Nickel starting January 1, 2020.

The implementation of the law has resulted in many offers from overseas companies openly expressing interest in investing by establishing a Refining Processing Company for raw nickel mining products in Indonesia. According to the statement, According to the Director General of Mineral and Coal (Minerba) of the Ministry of Energy and Mineral Resources (ESDM), Mr. Thamrin Sihite, the high offer of foreign investment interest to establish a refining company for nickel mining products proves that the Government's policy to stop the export of raw mining materials nickel in 2014 opened up more opportunities for foreigners to invest in Indonesia to bring in foreign exchange for the country.

Author Looking for and studying data and research related to government decisions regarding the obligation to process nickel mining products before exporting, we did not find much research associated with applying tax provisions, especially policies on the application of international Taxation.

\section{THEORETICAL BASIS}

The Government, responding to the offer of investors from other countries to invest in the country to establish a processing and refining company for mining products, must of course, refer to the provisions of the relevant state administration, in this case, Law no. 25 of 2007 concerning investment, as stated in the Legislative Provisions quoted from the Investment Law Book by Salim Said 2008 Page 175. For a business entity with a foreign investment status, the legislators require the business entity to be in the form of a Limited Liability Company (PT). One of the requirements for a foreign legal entity to become a limited liability company is that the foreign legal entity must cooperate with a domestic legal entity. Cooperation between foreign legal entities and domestic legal entities is stated in the joint venture contract. This contract regulates the distribution of shares. Foreign parties can own a maximum of $95 \%$ and domestic a minimum of 5\%. A new legal entity will be formed from this cooperation, which is a combination of a foreign legal entity and a domestic legal entity.

The income earned by the state every year increases, especially from the Nickel Mining sector. Paying taxes on mining products is a burden for companies, especially for companies that have cross-border transactions. To avoid double Taxation, taxpayers in their taxation practices will carry out transfer pricing, enabling tax evasion, even tax evasion (tax smuggling), and other illegal actions to reduce the tax burden that must be paid. Of course, this will be detrimental to the state, where the state income obtained is not effective and maximal.

With the rapid development in international business transactions, the Company aims to develop its business globally, including crossborder trade. International trade relations should be held, where these activities aim to encourage countries to expand their trading activities.

In the theory of international transactions, there is competition and dependence that can generate profits. It is also possible to experience losses, in this case, can be regarded as a threat. When viewed from the perspective of tax revenue, income derived from international transactions will benefit the domestic economy and increase the source of payment of the source country. However, on the other hand, the development of technology and information, differences in tax rates, and the provision of tax facilities and tax planning internationally or globally will give birth to problems in the form of imposition of multiple taxes on the same object from international transactions on the same tax subject, due to the interests of 2 or more countries that have tax interests in it.

The influence of globalization has given rise to various kinds of tax avoidance practices, especially for multinational companies or companies operating across national borders (international trade).

In this case, there are differences in the applicable law. These legal differences can create gaps that allow entrepreneurs to avoid tax payments and take advantage of legal loopholes that aim to avoid tax, which is, of course, based on a lawful provision. On the other hand, the taxpayer's tax smuggling act is also possible, both in the source country and destination country, where the taxpayer intentionally does not pay taxes or does not report taxes. Of course, it violates the provisions of applicable tax law Tax evasion is an illegal activity. Tax avoidance methods that entrepreneurs in international trade often use are as follows:

1. Transfer Pricing, namely the act of setting a certain amount of price for the delivery of goods or services in terms of procurement in an agreed manner by companies that have special relationships, of course, the practice is carried out with the mechanism of international business transactions. The purpose of transfer pricing is to minimize the tax burden to be paid by the Company.

2. Tax Haven Country, according to Spitz's opinion in Ning Rahayu, Tax Haven is related to the jurisdiction where there is no tax, the tax is only imposed on certain transactions, and low rates on income earned from abroad is special treatment for certain transactions. Meanwhile, according to Zain Dalam Ning Rahayu, the State Tax Haven can be interpreted. First, there is no tax imposition, or if there is a tax collection, a low tax rate is used. Second, a country has strict regulations regarding 
bank secrets and business secrets, and there is no opportunity to disclose these secrets to any party. Third, there is weak supervision of foreign exchange flows, including deposits from abroad, whether directed to individuals or business entities.

3. Thin Capitalization refers to a situation where a company has a much larger amount of debt than the amount of capital or is often called 'highly leveraged' (OECD, 2012). The Taxation of corporate income can result in double Taxation, where the first Taxation is on corporate income and the double Taxation is on dividend payments. Therefore, financing through debt will be more profitable for the Company.

4. Controlled Foreign Corporation uses tax avoidance by establishing a company abroad, where the domestic taxpayer (WPDN) has control. In this case, the WPDN seeks to reduce the amount of tax payable on investments made abroad by retaining profits distributed to shareholders. So that WPDN can avoid Taxation on dividend income.

Thus, to prevent double taxation problems in international business transactions, countries can enter into double taxation avoidance agreements through tax treaties. In a tax treaty, the tax subject of a foreign company is usually in the form of a Permanent Business Entity (BUT) because this provision has become standard terminology in international tax provisions. In practice, BUT is treated as a foreign taxpayer (WPLN). In-Law no. 8 of 1967 concerning amendments and improvements to the 1944 Income Tax, the 1932 Wealth Tax, and the 1925 Company Tax placing BUT as a foreign tax subject. However, article 2 paragraph 3 (c) of Law no. 7 of 1983 places BUT as a domestic tax subject. Finally, Law no. 10 of 1998 concerning Banking returns the status of BUT to its legal basis as a business entity that earns income from WPLN companies.

In connection with the avoidance of double Taxation through tax treaties between countries or commonly called tax treaties, it is based on that each country has international taxation sovereignty and applies principles that will benefit the country. State sovereignty in regulating taxation provisions may differ and conflict with the implementation of other countries' tax systems, resulting in the emergence of tax collection rights by two different countries. Each country has the authority to collect taxes based on points of connection. Herein lies the importance of an agreement's presence to avoid double Taxation between two countries. This agreement was formed based on a long process of compromise, in which the activity is based on the extent to which a government regulates its international taxation rights. An agreement to avoid double Taxation is a juridical avoidance of taxes. The articles in the contract are essentially distributive rules, namely dividing the taxation rights of two countries.

In other words, to prevent double Taxation, the state can enter into a double taxation avoidance agreement in the form of a tax treaty. Therefore, the author in this journal article will discuss "INTERNATIONAL TAX JURISDICTION REVIEW OF GOVERNMENT DECISIONS CONCERNING THE OBLIGATION TO PROCESS NICKEL MINING PRODUCTS BEFORE EXPORTING."

\section{RESEARCH METHODS}

The research method in this journal is a literature review from various policy scientific sources. Epistemologically, the ideal policy is determined based on the results of research and development. The development of modern life allows the concepts of research and policy to be accommodated in a harmonious atmosphere. Research policies and information from other parties involved in policymaking, in terms of policy research, some of them are stakeholders (Meha, 2010, Widyatama, 2013). In line with Rahayu (2011), the policies referred to as the background for policy research are actions intended to solve problems. Problem-solving by policymakers, in this case, is carried out based on recommendations and references made by policy researchers based on the results of their research.

\section{TOPIC DISCUSSION}

This study aims to find out the application of the double taxation avoidance agreement in the form of a Tax Treaty between Indonesia and other countries from the Juridical aspect of Tax Application. Specifically, the purpose of this study is to find out the legal aspects of international Taxation regarding tax treaties as international legal provisions in avoiding double Taxation between Indonesia and other countries in connection with foreign investment in Indonesia in connection with the Government's Decree on the Obligation to Process Mine Production in Indonesia before being exported.

This research is expected to provide benefits to readers regarding tax treaties between Indonesia and other countries studied in terms of international trade. The following will describe the theoretical advantages and practical gifts that are expected to be received by readers, namely:

\section{Theoretical Benefits}

Theoretical benefits are related to educational benefits, where this research is expected to increase readers' knowledge about tax treaties between Indonesia and other countries.

2. Practical Benefits

This research is expected to provide benefits for companies, especially for Permanent Business Entities regarding double Taxation, double taxation avoidance agreements in the form of tax treaties between Indonesia and other countries, and their relationship in the growth of international trade law.

Growing international trade, countries generally sign agreements containing taxation issues that can affect the development of international trade. The treaty or agreement contained herein contains provisions for tax reduction (withholding tax) for companies established overseas, including branch companies and subsidiaries. This tax treaty is known as a tax treaty. There is an understanding of Tax Treaty according to experts, namely as follows:

I. According to Surahmat (2000)

This publication is licensed under Creative Commons Attribution CC BY.

http://dx.doi.org/10.29322/IJSRP.11.08.2021.p11607

WWW.ijsrp.org 
A tax treaty is "a reconciliation of two different tax laws and regulations to divide taxation rights and avoid double taxation caused by the existence of juridical double taxation or conflicts in the implementation of the taxation rules of two countries."

II. According to Isenbergh (1997)

A tax treaty is "an agreement between two countries which consists of a series of rules and concessions that are mutually beneficial in terms of tax laws between these countries."

In terms of legislation in Indonesia itself, there are basic regulations that regulate it, which are as follows:

The provisions of the Tax Treaty regulations are regulated in Article 32 A of the Income Tax Law, which means that a special legal instrument is required to improve economic and trade relations with other countries (lex specialist).

Based on article 2 Per-25/PJ/2018 concerning Procedures for Approval for the Avoidance of Double Taxation, WPLNs who earn income from Indonesia can benefit from the tax treaty following the provisions stipulated in the agreement if:

1. Income recipients are not Indonesian domestic tax subjects.

2. The income recipient is an individual or entity that is a domestic tax subject from the partner country or the double taxation avoidance agreement (P3B).

3. There is no misuse of $\mathrm{P} 3 \mathrm{~B}$.

4. The income recipient is the beneficial owner if required in the P3B.

In Article 4 paragraph 1 Per-25/PJ/2018 concerning Procedures for Approval for the Avoidance of Double Taxation, there are administrative requirements that WPLNs must meet in using the Tax Treaty, namely the submission of a Certificate of Domicile (SKD) to the tax withholder/collector by:

1. Using the DGT (Directorate General Of Tax) Form

2. Filled incorrectly, completely, and clearly,

3. Signed or given a signature equivalent to the signature by WPLN following the custom in the partner country or P3B partner jurisdiction.

4. It is ratified by being signed or given a sign equivalent to a signature by an authorized official following the custom in the partner country or the jurisdiction of the P3B partner.

5. There is a statement by WPLN that there is no misuse of P3B.

6. There is a statement by the WPLN that the WPLN is the beneficial owner.

7. They were used for the period listed in the SKD WPLN.

The tax collector collects the tax payable on the income earned by the taxpayer under the Income Tax Law. However, if a WPLN submits a WPLN SKD, then the tax collector is obliged to collect the tax payable based on the provisions in the tax avoidance agreement.

Based on article 5 Per-25/PJ/2018, a taxpayer is declared not to have abused the Tax Treaty if:

1. WPLN has:

a. economic substance in the establishment of the entity or the conduct of transactions.

b. The legal form is the same as the economic substance in establishing the entity or executing trades.

c. The management itself manages business activities, and the administration has sufficient authority to carry out transactions.

d. The Fixed assets and non-fixed assets are sufficient to carry out business activities in partner countries or jurisdictions of P3B partners other than assets that generate income from Indonesia.

e. The Company has a Sufficient and adequate number of employees with certain expertise and skills under the line of business run by the Company.

f. Activities of businesses that were only receiving income in dividends, interest, or royalties sourcing from Indonesia.

2. There is no transaction arrangement either directly or indirectly to obtain benefits from the implementation of the Tax Treaty, including:

a. reduction of the tax burden, and/or

b. Taxation is not imposed in any country or jurisdiction (double non-taxation), which is contrary to the intent and purpose of establishing the Tax Treaty.

Regarding the beneficial owner, it is regulated in article 6 Per-25/PJ/2018, where the WPLN fulfills the provisions as a Beneficial Owner if:

1. for an individual WPLN, does not act as an Agent or Nominee;

or

2. for corporate WPLN, must meet the following conditions:

a. not act as Agent, Nominee, or Conduit.

b. Have control over the use or enjoyment of funds, assets, or rights that generate income from Indonesia.

c. Not more than $50 \%$ of the Company's income is used to fulfill obligations to other parties. 
d. Bear the risk of the assets, capital, or own liabilities.

e. Has no obligation, written or unwritten, to pass on part or all of the income received from Indonesia to other parties.

The author describes the implementation of the stipulation of the provisions of this Tax Treaty taking the Case Study of the Agreement for the Avoidance of Double Taxation in Indonesia - the Netherlands submitted by Ratyan Noer Hartiko from the University of Indonesia in 2012, the Tax Treaty between Indonesia and the Netherlands using a mixed-method in the form of Corporation and Development (OECD) and the United Nations (United Nations). UN), which is applied for Indonesian tax purposes. The bilateral agreement has also been renegotiated. Because the Indonesia - Netherlands tax treaty is still far from perfect. The regulation on income tax has been amended four times, and on wealth tax which has not been regulated in the tax treaty. In another example, citing in the thesis entitled Indonesia-Malaysia Bilateral Agreement by Khairul Anwar from the University of North Sumatra in 2005, the tax treaty model between Indonesia and Malaysia uses the UN model, where both countries are developing countries. Foreign investors who wish to invest can form a legal entity in a Permanent Establishment (BUT).

From the example of the case study related to the agreement above, it can be seen that there are differences in the use of the bilateral agreement model used by Indonesia in making double taxation avoidance agreements with other countries. Therefore, the author conducts research and describes the tax treaty in general to avoid double Taxation in permanent business entities.

A tax treaty is an agreement to avoid double Taxation, which contains an understanding between the two countries to regulate tax provisions based on national, regional, and world regulations. These can be divided into five categories, which are as follows:

1. International movement of goods. Namely the global trade in goods.

2. Invisible trades. Namely, the existence of business in services that cross national borders.

3. International movement of persons. Namely the existence of foreign workers who enter a country.

4. Foreign investors are given the obligation to monitor their capital directly.

5. Foreign exchange transactions. Namely international payments, where there are transactions related to the exchange of foreign currencies.

Each country has a different quality of natural resources, climate, and labor. Thus, based on Ricardian theory, the efficient allocation of existing resources in a market is very important. The Government must reduce the obstacles that may reduce the quality of the efficiency function in the global market.

In the implementation of foreign investment in the nickel mining raw material processing industry sector in Indonesia, concerning the five categories above, of course, transactional performance will result in international transactions of goods and services such for example entering initial business capital, procurement of processing technology, processing raw materials, machine maintenance. And processing equipment, use of management services, human resource services related to technology, processing machinery, equipment, etc. From what is exemplified, of course, there is a mechanism for trade or service transactions that cross national borders, foreign workers entering the Unitary State of the Republic of Indonesia will eventually get an international payment mechanism in it.

In addition to indicators to detect international cooperation, provisions for liberalization of international trade are also needed in maintaining the appropriateness of international collaboration were focusing on the WTO (World Trade Organization), so that it becomes an influence and reference that must be agreed upon in the international agreement, especially member countries. WTO.

The basic principles of the WTO are as follows:

\section{Non-Discrimination}

In the principle of non-discrimination, there are two aspects, namely:

a. Most favorite Nation. This principle is regulated in Article 1, paragraph 1 of the GATT (General Agreement on Tariffs and Trade) 1947, which states that every trade policy, both imports and exports, and other costs must be carried out without any discriminatory actions. All member countries are obliged to provide the same treatment and efforts to other member countries.

b. National Treatment. This principle is regulated in article 3 of the GATT 1947. Based on this principle, imported products imported from one country to another must be treated equally with domestic products. On the other hand, this principle applies to the tax system and legislation that affects buying and selling, transporting, distributing, or using products from within the country. Therefore, this principle protects the state from the risk of implementing Government and administrative efforts or policies.

\section{Liberalization of Trade}

The WTO aims to provide stability and certainty in the international trade process. Liberalization is the key to removing restrictions on export and import activities. On the other hand, although the WTO's goal is to create liberal trade, the process of liberalization also has certain limitations.

The limits referred to as safeguards are in the form of "a further special agreement on safeguards and the special case of textiles." It means that it prevents fatal consequences for a country. Safeguards provide freedom for that country to make sudden actions.

\section{No unfair trade}

Namely, the prohibition of unfair actions in international trade. Unfair trading in question is as follows: 
a. Dumping. It is dumping as predatory pricing. Dumping is stated as an act of price discrimination in which a producer intentionally sells goods and/or services below the price, intending to eliminate competitors. Antidumping is allowed if it is carried out to protect the country's economy in the face of unfair competition, not only to protect the Company's trading conditions the regulation in article 6 of the GATT 1947.

b. Subsidy. Regarding subsidies, it is regulated in articles 16, 17, and 18 of the GAAT 1947. In the eighth multilateral trade negotiations of the GATT, subsidies are defined as "a financial contribution by the Government or any public body where the government practice involves the following:

I. A direct transfer of funds

II. Potential direct transfers of liabilities

III. Government revenue (for instance, taxation and payroll duty) that is otherwise due is foregone

IV. Government provisions of goods or services other than general infrastructure

V. Government payments to a funding mechanism or direction to a private body to carry out the above functions.

Subsidies are prohibited if they can cause interference in international trade. On the other hand, there are several types of offerings that GATT allows, such as:

I. Under article 18 of the GATT, member states can grant special concessions to certain domestic industries.

II. Subsidies can be given to reduce tariff discrimination.

III. Subsidies can limit the number of imported products, of course, to develop domestic industries.

IV. The implementation of the provision of subsidies does not violate the provisions of notification and negotiation. For example: in article 16 of the GATT 1947, a member country that subsidizes its foreign trade is obliged to notify the recipient country regarding the subsidized goods or services. Furthermore, the procedures for use or procedures must be discussed together.

\section{Transparency}

The main key to transparency is to increase the trust of business actors. Business actors certainly want the domestic legal system to treat foreign residents as equals to residents. There are several issues related to transparency, that is:
a. Publish rules or laws
b. There is a uniform, not separate, and administrative system that is
c. acceptable from a rule and law.
d. There is applied judicial review of administrative decisions.

\section{Exception}

That is related to exceptions in WTO principles.

A. General Exceptions. The regulation in article 20 of the GATT 1947. That is related to horizontal exceptions (horizontal exceptions). The exceptions in question are in the form of:

a. To protect public morals. That is the moral Protection of the people.

b. To protect humans, animals, or the life of the planet or health. Namely, the Protection of humans, animals, or planet earth life or health.

c. Related to the gold or silver importation or exportation. Namely relating to the sale of gold and silver, either import or export

d. To secure the compliance of law or regulations which are not in accord with the agreement includes:

1) The enforcement of custom

2) The Protection of patents, trademarks, and copyright

3) The monopolies enforcement

4) To prevent deceptive actions

e. Products produced by prison labor.

f. It is conducted to protect artistic heritage, history, and things that contain the archaeological value

g. Lack of the conservation of resources.

h. It's taken due to the occurrence of liability from the government commodity agreement.

i. Involving the restriction on the export of domestic materials is crucial to ensure the main quality of the materials for the domestic industry during the period when the domestic price for the materials is below the world price, which is part of the government stabilization plan. Such restriction shall not increase the export or protect domestic industry and shall not deviate from the non-discrimination agreement.

j. It is essential to acquire or distribute general or local products for short-term supply. 
B. Security Exceptions, i.e., the state has the right to protect itself from attacks by other countries. WTO member countries are countries that have sovereignty and responsibility for their national security. Based on Article 24 of the GATT, treatment can be done if there is a regional free trade agreement such as NAFTA, EU, etc.

\section{CONCLUSION}

Based on the descriptions above regarding the Tax Treaty and its relation to international trade law, it can be concluded that:

1. The purpose of the Mining Law Number 4 of 2009 concerning the obligation to process refining for raw minerals before export is carried out is to provide increased added value to the results of natural mineral resources, in this case, nickel ore production. Of course, the statutory provisions have implications for the interest from other countries to bring or invest in Indonesia because Indonesia is the 4th largest country as the largest nickel ore producer in the world.

2. Double Taxation is the imposition of the same type of tax by two or more different countries on a tax subject and the same tax object in the same tax period (Juridical tax). The elements in international double Taxation are the existence of the relevant party who collects the tax, the same subject, the same object, the same tax, and the same time. The impact of double Taxation on international trade is on the financing of business. Double Taxation will harm the country's economic growth and increase crime in the field of Taxation, such as tax evasion, tax evasion, tax smuggling, and so on, because the payment of taxes is a burden on the Company. The increasing number of taxes, especially double taxes, will reduce the motivation of companies to develop or expand trade. Thus, the country's economic growth will be hampered. In international trade, there are also fiscal and non-fiscal barriers. Therefore, the provisions of the Tax Treaty between Indonesia and other countries are arranged so that there is an understanding that is mutually beneficial and has implications for the growth of each country's revenue without anyone being harmed.

3. Regulations per legislation regulate the basic rules in determining the source of income. Determination of the origin of income is very important to be able to benefit from the tax treaty. In Indonesia, the provisions of the Tax Treaty regulations are regulated in Article $32 \mathrm{~A}$ of the Income Tax Law, meaning that in the context of improving economic and trade relations with other countries, a special applicable legal instrument (lex specialist) is required in the form of regulations / derivative provisions such as Per-25 / PJ/2018 concerning Procedures for Double Taxation Avoidance Approval.

\section{REFERENCES}

[1] Kementerian ESDM. (2018, Mei 15). Permen ESDM No.25 Tahun 2018. Regulation . Jakarta, DKI Jakarta, Indonesia.

[2] Adolf, H. Hukum Perdagangan Internasional, Ed. 4, Jakarta: Rajawali Press, 2011.

[3] Andi Amran Sulaiman, Et Al. Perdagangan Internasional Komoditas PanganvStrategis. Jakarta: IAARD Press, 2018 .

[4] Budiono, G., L. Bisnis Internasional. Jakarta: Febsos, 2019.

[5] Darussalam. \& Septriadi, D. Perjanjian Penghindaran Pajak Berganda. Jakarta:DDTC, 2017.

[6] Dirdjosisworo, S. Pengantar Hukum Dagang Internasional. Bandung: PT. Refika Aditama, 2006.

[7] Halim, A., et al. Perpajakan, edisi 2. Jakarta: Salemba Empat, 2017.

[8] Pohan, C., A. Perpajakan Indonesia Teori dan Kasus. Jakarta: Mitra Wacana Media, 2014.

Soekanto, S. Pengantar Penelitian Hukum. Jakarta: UI Press, 2018.

[9] Soemitro, R. Hukum Pajak Internasional Indonesia. Bandung: PT. Eresco, 1986.

[10] Surahmat, R. Persetujuan Penghindaran Pajak Berganda, Sebuah Pengatar. Jakarta: PT.Gramedia

Pustaka Utama, 2000.

[11] Utama, M. Hukum Ekonomi Internasional. Jakarta: PT. Fikahati Aneska, 2012. 
[12] Waluyo. Perpajakan Indonesia, Buku 1, Edisi 4. Jakarta: Salemba Empat, 2008.

[13] Sentosa Sembiring, Hukum Investasi. Pembahasan dilengkapi dengan Undang-Undang no 25 Tahun 2007 Tentang Penanaman Modal, Bandung: Nuansa Aulia, 2007

[14] Salim HS dan Budi Sutrisno, Hukum Investasi di Indonesia, Jakarta: PT. Rajagrafindo, Persada, 2008

First Author - Agus Tyono Amas Noer, Graduated Student, Institute STIAMI Jakarta and agustyono@gmail.com.

Correspondence Author - Agus Tyono Amas Noer, agustyono@gmail.com, 085399918881. 